\title{
External pancreatic secretion after bombesin infusion in $\operatorname{man}^{1}$
}

\author{
NICOLA BASSO ${ }^{2}$, SERGIO GIRI, GIOVANNA IMPROTA, EMANUELE LEZOCHE, \\ PIETRO MELCHIORRI, MASSIMO PERCOCO, AND VINCENZO SPERANZA
}

From Istituto III Patologia Chirurgica and Istituto di Farmacologia, Universitá di Roma, Rome, Italy

SUMMARY The effect of bombesin on external pancreatic secretion was studied in seven healthy volunteers and in two patients with a two-thirds gastrectomy and a pancreatic fistula. After bombesin infusion $(15 \mathrm{ng} / \mathrm{kg} / \mathrm{min})$, gastrin levels were significantly raised in all volunteers, but remained at basal levels in the gastrectomized patients. Bombesin was effective in stimulating pancreatic secretion in all patients. The volume of secretion increased two-fold when compared with basal volume. Amylase and trypsin concentrations and outputs in the duodenal juice were greatly augmented (amylase concentration: basal, 70 dye $\mathrm{U} / \mathrm{ml}$; post-bombesin, 620 dye $\mathrm{U} / \mathrm{ml}$. Amylase output: basal, 1000 dye U/15 min; post-bombesin, 15,800 dye U/15 min). Secretin, when administered in conjunction with bombesin, partially inhibited its secretory effect. Bicarbonate secretion was slightly stimulated by bombesin, but at a very low level. A similar pattern of results was obtained in the two gastrectomized patients. In man, bombesin exerts an effect on pancreatic secretion that mimics the effect of CCK-PZ, thus confirming the results obtained in the experimental animal. Gastrin does not play a fundamental role in this phenomenon.

Bombesin (Pyr-Gln-Arg-Leu-Gly-Asn-Gln-Tpr-AlaVal-Gly-His-Leu-Met- $\mathrm{NH}_{2}$ ), an active tetradecapeptide isolated by Anastasi et al. (1971), is a very potent stimulant of gastrin secretion in the experimental animal (Basso et al., 1974) and in man (Melchiorri et al., 1973; Basso et al., 1975).

Recent experiments showed that bombesin is capable of contracting the gallbladder in the dog (Erspamer et al., 1974; 1975) and in man (Corazziari et al., 1974).

The secretion of enzymes from the pancreas was elicited by bombesin administration in the dog (Erspamer et al., 1975). Cholecystokinin release by bombesin has been postulated.

At present, the effect of bombesin on external pancreatic secretion in man is not known.

\section{Methods}

Two groups of patients, group A (seven healthy young male volunteers) and group B (two patients

${ }^{1}$ Research carried out with a grant from C.N.R. no. 72.00893.04.

'Address for correspondence: Dr Nicola Basso, Istituto III Patologia Chirurgica, Policlinico Umberto I ${ }^{\circ}$, Università di Roma, Rome, Italy. 'Synthesized in Farmitalia S.p.a. Laboratories, Milan.

Received for publication 3 September 1975. with two-thirds gastrectomy and external pancreatic fistula) were studied.

In the control group, after a 12-hour overnight fast, a double-lumen radiopaque tube was positioned in the fourth portion of the duodenum before the ligament of Treitz under fluoroscopic control.

A nasogastric Levin tube was placed in the most dependent portion of the stomach. The Levin tube and the distal end of the double-lumen duodenal tube were aspirated by continuous hand suction. The proximal end of the duodenal tube was connected to a constant infusion Harvard pump.

Polyethylene glycol 1:100 (5 ml/min) was infused.

A constant infusion of saline was started in an arm vein for $\mathbf{3 0}$ minutes.

Then bombesin ${ }^{3} 15 \mathrm{ng} / \mathrm{kg} / \mathrm{min}$ intravenously was injected for 90 minutes.

During the final $\mathbf{3 0}$ minutes of bombesin infusion, $1.7 \mathrm{U} / \mathrm{kg} / \mathrm{h}$ Secretin (Jorpes) was infused intravenously. Secretin alone was infused at the same dose level for a further $\mathbf{3 0}$ minutes. Finally, saline was infused for 30 minutes.

Gastric juice and duodenal juice were collected throughout the experiment every 15 minutes. The volume was calculated by correcting the incomplete 
recovery of duodenal juice according to the technique of Go et al. (1970). In the two patients with a two-thirds gastrectomy and pancreatic fistula the same protocol was followed except that pancreatic juice was collected directly from the cutaneous orifice of the fistula. Gastric juice was collected and discarded.

Acid concentration in the gastric juice was measured by titrating to $\mathrm{pH} 7$ with $0.1 \mathrm{~N} \mathrm{NaOH}$ by means of an autoburette using a pH meter (Radiometer-Copenhagen). On each sample of duodenal juice the following measurements were made: volume $(\mathrm{ml} / 15 \mathrm{~min})$; amylase activity concentration (dye $\mathrm{U} / \mathrm{ml}$ ), by a chromometric method (amylochrome test, Roche Diagnostics) (Take et al., 1969; Klein et al., 1970; Dalal and Winsten, 1971) with buffered dyed polysaccharide as substrate and $\mathrm{NaH}_{2} \mathrm{PO}_{4}$ at $\mathrm{pH} \mathrm{4.3}$ as diluent; amylase activity output (dye U/15 min); trypsin activity concentration $(\mathrm{mU} / \mathrm{ml})$, by a colorimetric method using $\mathrm{H}-$ benzoylarginine-p-nitramilide as substrate and a solution containing tris buffer and $\mathbf{C a C l}_{\mathbf{2}}$ as diluent (Erlanger et al., 1961; Ritter, 1971); trypsin activity output was calculated as $\mathrm{mU} / 15 \mathrm{~min}$; bicarbonate concentration (mequiv/ml) was determined by indirect titration with $\mathrm{NaOH}$ after adding $\mathrm{HCl}$ and boiling, the residual acid was back titrated to $\mathrm{pH}$ 7.0 with $0.1 \mathrm{~N} \mathrm{NaOH}$; bicarbonate output was calculated as mequiv/15 min.

Throughout the experiments, $5 \mathrm{ml}$ blood samples were taken every 15 minutes. The blood was allowed to coagulate and the serum was immediately separated by cold centrifugation $\left(5^{\circ} \mathrm{C}\right)$ and maintained at $-20^{\circ} \mathrm{C}$ until the radioimmunoassay was performed.

Gastrin levels were measured according to the method described by Stern and Walsh (1973). Antibody n. 2604 (kindly supplied by Dr J. F. Rehfeld) was used (Rehfeld et al., 1972; Stadil et al., 1973). All samples of sera were measured in duplicate. The difference of gastrin values never exceeded $10 \%$. The statistical significance of observed differences was determined by means of Student's $t$ test for paired couples.

All results were expressed as mean \pm standard error of the mean (SEM) of the data obtained in seven tests (group A). The results in group B were expressed as the mean of the data obtained in two tests.

\section{Results}

GROUP A: GASTRIC RESPONSE

Bombesin stimulated gastrin secretion from a basal value of $85 \mathrm{pg} / \mathrm{ml}$ to a peak value of $280 \mathrm{pg} / \mathrm{ml} 45$ minutes after bombesin infusion.
Secretin infusion did not significantly alter the gastrin response to bombesin $(P>0.05)$, while lowering gastrin levels when the bombesin infusion was interrupted. At the end of the final $\mathbf{3 0}$ minutes of saline infusion, gastrin levels were near to basal values (Fig. 1).

Gastric acid secretion was $2.0 \mathrm{mEq} / 15 \mathrm{~min}$ in basal conditions and $3.7 \mathrm{mEq} / 15 \mathrm{~min}$ after 60 minutes of bombesin infusion. Secretin, when administered in conjunction with bombesin, significantly lowered the acid output $(P<0.05)$. At the end of the test gastric acid output returned to near basal levels (Fig. 2).

\section{GROUP A: PANCREATIC RESPONSE}

The basal volume of duodenal juice was $15 \mathrm{ml} / 15$ min. During bombesin infusion, a peak response of $35 \mathrm{ml} / 15 \mathrm{~min}$ (difference statistically significant: $P<0.05)$ was measured. Secretin, when adminisstered in conjunction with bombesin, elicited a volume response of $65 \mathrm{ml} / 15 \mathrm{~min}$. When secretin was infused without bombesin infusion, the volume response was the highest obtained throughout the test, $150 \mathrm{ml} / 15 \mathrm{~min}$. Discontinuing secretin infusion resulted in an abrupt fall of volume to near basal levels (Fig. 3).

Amylase secretion was greatly increased after bombesin infusion: from a basal concentration of 70 dye $\mathrm{U} / \mathrm{ml}$ and a basal output of 1000 dye $\mathrm{U} / 15$ min to a concentration of 620 dye $U / \mathrm{ml}$ and a peak

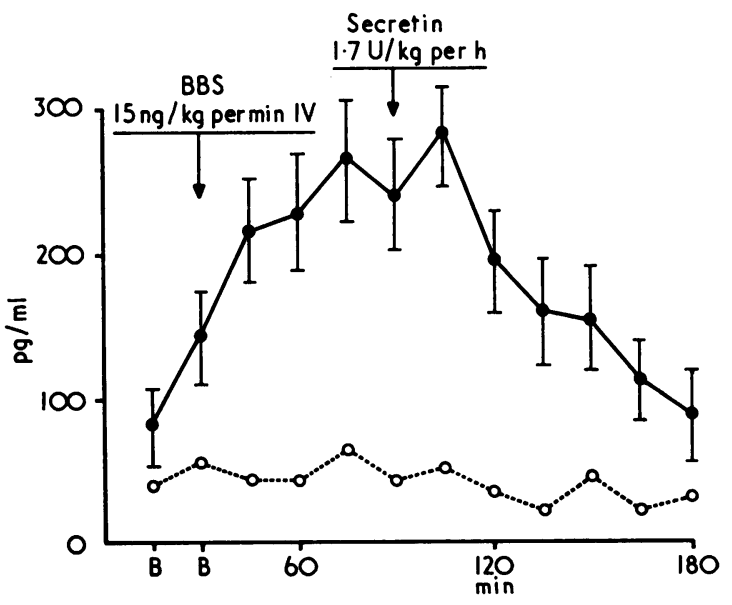

Fig. 1 Serum gastrin levels in basal conditions and after administration of bombesin, bombesin in conjunction with secretin, and secretin. 1 mean \pm SEM of the results obtained in seven experiments in seven healthy volunteers. $O:$ mean of the results obtained in two experiments in two patients with two-thirds gastrectomy and external pancreatic fistula. 


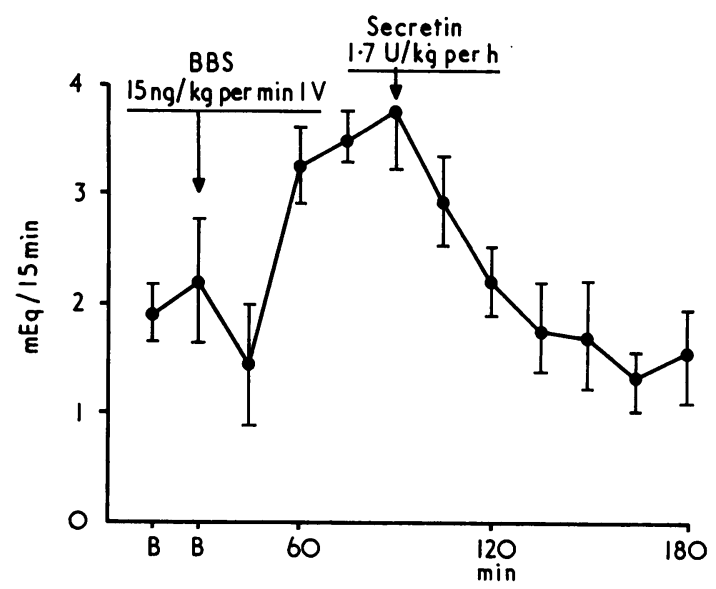

Fig. 2 Gastric acid output in basal conditions and after administration of bombesin, bombesin in conjunction with secretin, and secretin. Key as in Fig. 1 .

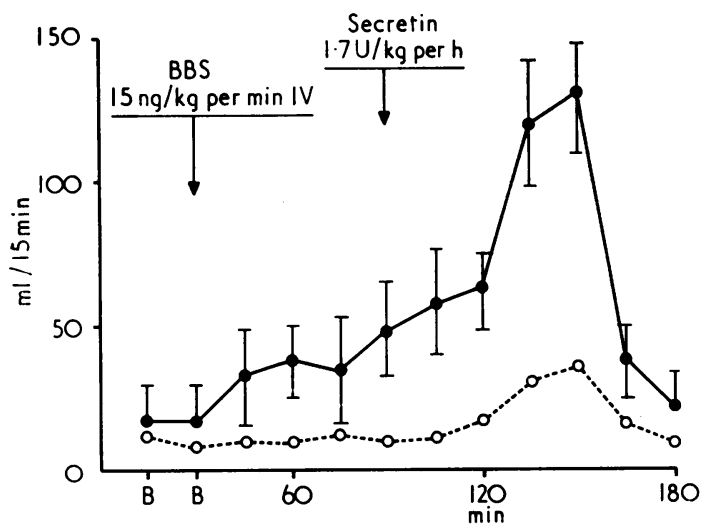

Fig. 3 Volume of duodenal aspirate in basal conditions and after administration of bombesin, bombesin in conjunction with secretin, and secretin. Key as in Fig. 1.

output of 15,800 dye $\mathrm{U} / 15$ min 30 minutes after bombesin infusion.

When bombesin was administered in conjunction with secretin, amylase concentration and amylase output were lowered to 175 dye $\mathrm{U} / \mathrm{ml}$ and 9500 dye $\mathrm{U} / 15 \mathrm{~min}$ respectively.

Discontinuing bombesin infusion while administering secretin resulted in a further lowering of amylase concentration and amylase output to near basal levels (Fig. 4).

A similar pattern of responses was obtained when trypsin was measured in the duodenal juice (basal concentration: $24 \mathrm{mU} / \mathrm{ml}$; output: $250 \mathrm{mU} / 15 \mathrm{~min}$. Post-bombesin concentration: $112 \mathrm{mU} / \mathrm{ml}$; output

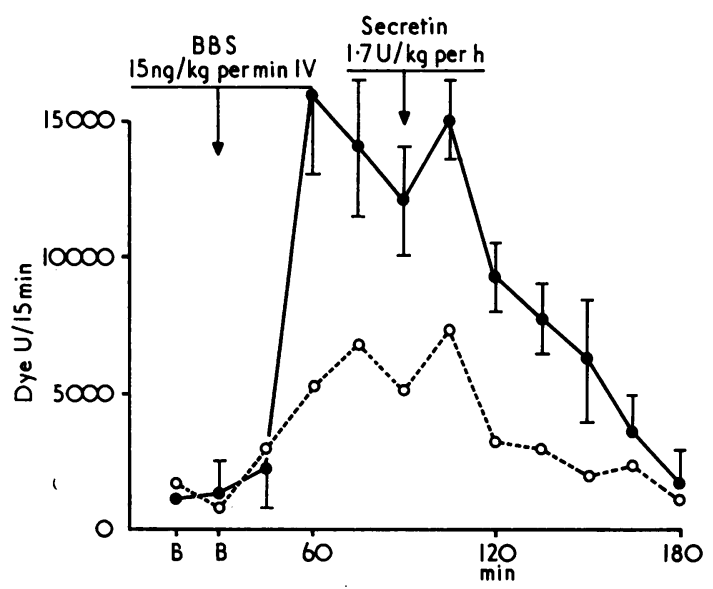

Fig. 4 Amylase output in the duodenal aspirate in basal conditions and after administration of bombesin, bombesin in conjunction with secretin, and secretin. Key as in Fig. 1.

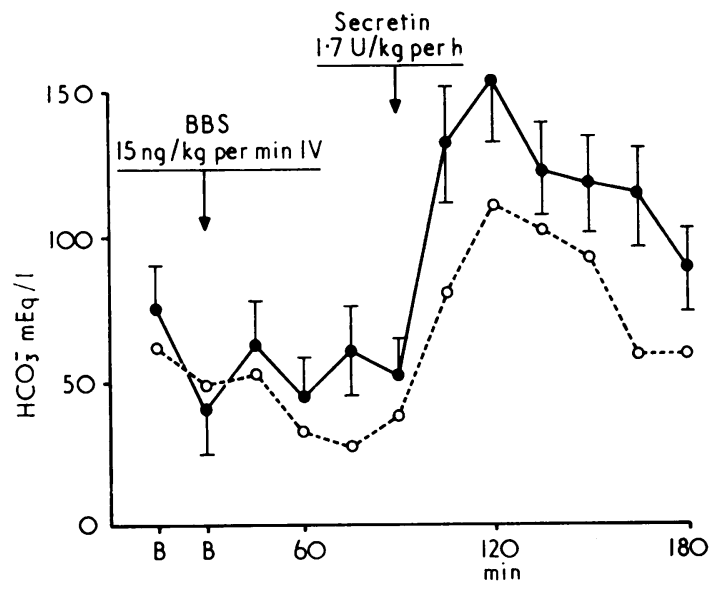

Fig. 5 Bicarbonate concentration in the duodenal aspirate in basal conditions and after administration of bombesin, bombesin in conjunction with secretin, and secretin. Key as in Fig. 1.

$1200 \mathrm{mU} / 15 \mathrm{~min})$. Bicarbonate concentration and output in the duodenal juice in basal conditions were $73 \mathrm{mEq} / \mathrm{l}$ and $1.3 \mathrm{mEq} / 15 \mathrm{~min}$, respectively.

After bombesin infusion, these values were 60 $\mathrm{mEq} / 1$ and $2.6 \mathrm{mEq} / 15 \mathrm{~min}$, respectively (not statistically different from basal values: $P>0.05$ ).

When secretin was administered in conjunction with bombesin, bicarbonate concentration increased to $153 \mathrm{mEq} / 1$ and bicarbonate output increased to $11.2 \mathrm{mEq} / 15 \mathrm{~min}$.

Discontinuing bombesin infusion while administering secretin resulted in a further increase of bicarbonate output $(16.3 \mathrm{mEq} / 15 \mathrm{~min}$, statistically significant: $P<0.05)$. Bicarbonate concentration 
was not significantly changed $(118 \mathrm{mEq} / \mathrm{l}, \mathrm{P}>$ 0.05).

At the end of the test, bicarbonate concentration and output returned at near basal values (Figs. 5 and 6).

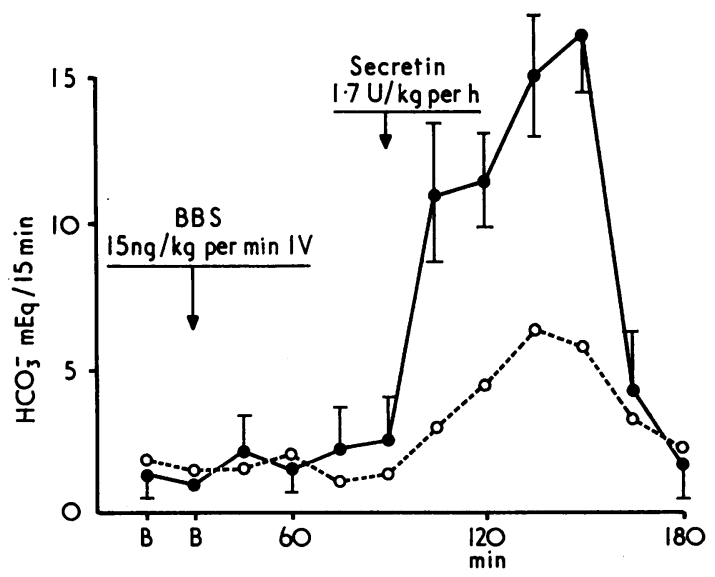

Fig. 6 Bicarbonate output in the duodenal aspirate in basal conditions and after administration of bombesin, bombesin in conjunction with secretin, and secretin. Key as in Fig. 1 .

\section{GROUP B}

In these patients, pancreatic responses to bombesin and secretin infusions were similar to those obtained in the control group (group A), except for the absolute values, which were consistently lower than the corresponding values in group A. Gastrin values were not significantly affected by bombesin infusion (Fig. 1).

\section{Discussion}

The data obtained in the present study confirmed that bombesin greatly stimulates gastric secretion (Bertaccini et al., 1974; Basso et al., 1974). The secretagogue effect on gastrin was not inhibited by secretin infusion. Bombesin was effective in stimulating pancreatic secretion. The volume of secretion showed a two-fold increase. The peak response occurred at 30 minutes and its value was well below the value obtained after secretin infusion.

The secretion of enzymes and of bicarbonate from the pancreas was differently affected by the infusion of bombesin.

Amylase and trypsin concentration and output in the duodenal juice were greatly augmented with a peak response both in concentration and output at 30 minutes. The trypsin response was more sustained, while rapidly decreasing thereafter.
Secretin, when administered in conjunction with bombesin, did not potentiate the secretory effect of bombesin, but partially inhibited it. Bicarbonate secretion was slightly stimulated by bombesin, but at a very low level when compared with the effect of secretin on bicarbonate secretion in the same patients.

The highest bicarbonate output was obtained when administering secretin alone and not when administering secretin in conjunction with bombesin. It is apparent from the above data that bombesin exerts on pancreatic secretion in man an effect that mimics the effect of cholecystokinin-pancreozymin, thus confirming the results obtained in the dog by Erspamer et al. (1974).

The hypotheses are:

1. Bombesin by itself has a cholecystokinin-pancreozymin-like effect on pancreatic secretion.

2. Bombesin stimulates the secretion of cholecystokinin-pancreozymin from the duodenum.

On the basis of the first hypothesis, the target organ of bombesin is the pancreas, on the basis of the second hypothesis its target is the duodenum.

From the data obtained in this work, it is not possible to substantiate either of the two hypotheses. The fact that bombesin did not potentiate the effect of bombesin may possibly indicate that the CCK-PZ like effect of bombesin is not related to endogenous release of 'physiological' CCK-PZ.

It was possible to rule out gastrin as a possible mediator of the effect of bombesin on pancreatic secretion. In fact, enzyme secretion was stimulated by bombesin in the two antrectomized patients in whom no gastrin effect was apparent. Furthermore, in dogs, antrectomy did not alter the pancreatic response to the administration of bombesin (Erspamer et al., 1974).

In conclusion, after bombesin administration, enzyme secretion from the pancreas is augmented. This may be related to a direct CCK-PZ-like effect of bombesin on the pancreas or to the release of CCK-PZ from the duodenum due to bombesin.

Gastrin release does not play a fundamental role in this phenomenon. Studies are needed further to elucidate the mechanism of action of bombesin on pancreatic secretion.

\section{References}

Anastasi, A., Erspamer, V., and Bucci, M. (1971). Isolation and structure of bombesin and alytesin, two analogous active peptides from the skin of the European amphibians Bombina and Alytes. Experientia, 27, 166-167.

Basso, N., Improta, G., Melchiorri, P., and Sopranzi, N. (1974). Gastrin release by bombesin in the antral pouch dog. Rendiconti di Gastroenterologia, 6, 95-98.

Basso, N., Lezoche, E., Materia, A., Giri, S., and Speranza, V. (1975). Effect of bombesin on extragastric gastrin in 
man. American Journal of Digestive Diseases, (In press).

Bertaccini, G., Erspamer, V., Melchiorri, P., and Sopranzi, N. (1974). Gastrin release by bombesin in the dog. British Journal of Pharmacology, 52, 219-225.

Corazziari, E., Torsoli, A., Melchiorri, P., and Delle Fave, G. F. (1974). Effect of bombesin on human gallbladder emptying. Rendconti di Gastroenterologia, 6, 52-54.

Dalal, F. R., and Winsten, S. (1971). Laboratory evaluation of a chromogenic amylase method. Clinica Chimica Acta, 32, 327-332.

Erlanger, B. F., Kokowsky, N., and Cohen, W. (1961). The preparation and properties of two new chromogenic substrates of trypsin. Archives of Biochemistry, 95, 271-278.

Erspamer, V., Improta, G., Melchiorri, P., and Sopranzi, N. (1974). Evidence of cholecystokinin release by bombesin in the dog. British Journal of Pharmacology, 52, 227-232.

Erspamer, V., Melchiorri, P., Sopranzi, N., and Improta, G. (1975). Effects of bombesin on pancreatic secretion and gallbladder motility in dogs. (In press).

Go, V. L. W., Hofmann, A. F., and Summerskill, W. H. J. (1970). Simultaneous measurements of total pancreatic biliary and gastric outputs in man using a perfusion technique. Gastroenterology, 58, 321-328.
Klein, B., Foreman, J. A., and Searcy, R. L. (1970). New chromogenic substrate for determination of serum amylase activity. Clinical Chemistry, 16, 32-38.

Melchiorri, P., Concolino, G., Sopranzi, N., and Conti, C. (1973). Presented at VI meeting of the International Study Group for Steroid Hormones 1973, December 6-8, Rome.

Rehfeld, J. H., Stadil, F., and Rubin, B. (1972). Production and evaluation of antibodies for the radioimmunoassay of gastrin. Scandinavian Journal of Clinical and Laboratory Investigation, 30, 221-232.

Ritter, U. (1971). Erkrankungen des exkretorischen Pankreas. Thieme: Stuttgart.

Stadil, F., and Rehfeld, J. F. (1973). Determination of gastrin in serum. An evaluation of the reliability of a radioimmunoassay. Scandinavian Journal of Gastroenterology, 8, 101-112.

Stern, D. H., and Walsh, J. H. (1973). Gastrin release in postoperative ulcer patients: evidence for release of duodenal gastrin. Gastroenterology, 64, 363-369.

Take, S., Berk, J. E., and Frihandler, L. (1969). Observations on a new simplified dye method for assessing amylase activity. Clinica Chimica Acta, 26, 533-537. 